[什算团 2] 上の尔件の $5 ち \log \sigma_{Z_{R}}=0.18$ のみが異なる とき, $Q_{R} / Q_{P}$ と $D_{50 P}$ はどらなるか。

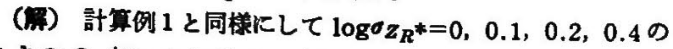
ときの $Q_{R} / Q_{P} お よ ひ ゙ ~ D_{50 P} / D_{50 F}$ を求めると,

$\begin{array}{ccc}\log \sigma_{Z_{R}} & Q_{R} / Q_{P} & D_{50 P} / D_{50 F} \\ 0 & 3.05 & 0.282 \\ 0.1 & 2.99 & 0.286 \\ 0.2 & 2.84 & 0.302 \\ 0.4 & 2.47 & 0.375\end{array}$

これらの值から $\log \sigma_{Z_{R}}$ と $Q_{R} / Q_{P}$ および $D_{50 P} / D_{505}$ との 閔保をプロットして, $\log \sigma_{Z_{R^{*}}}=0.18$ のときの数值を読むと， $Q_{R} / Q_{P}=\underline{2.87}$

$D_{50 P}=0.298 \times 50=\underline{15 \mu}$

[斗草例 3] ある分䄲機に $D_{50 F}=50 \mu, \log \sigma_{F}=0.4$ の原料 を送入し, $\log \sigma_{Z_{R^{*}}}=0.16, \alpha=0, \beta=0.2, Q_{R} / Q_{P}=2$ て運転 して $D_{50 P}=20 \mu$ とするためには， $D_{50}$ をいいくらにしなければ ならないか

(解) 式 (8) より

$$
\begin{aligned}
\log \left(\sigma_{Z_{B}}\right)_{0.5} & =(0.5 / 0.4) \log \left(\sigma_{Z_{R}} *\right)_{0.4} \\
& =1.25 \times 0.16=0.20
\end{aligned}
$$

したがって $\log \sigma_{F}=0.5$ のときの $\log \sigma_{z_{R}}=0.2$ のノモグラ

フを用いる。四2.2より，与えられた条件では $D_{50} * / D_{50}$
$=0.78$ そこで式 (7) より

$\left(D_{50} * / D_{50_{F}}\right)_{0.4}=\left(D_{50} * / D_{50 F}\right)_{0.5} 0.4 / 0.5=0.78^{0.80}=0.82$ $\therefore D_{50} * 0.82 \times 50=\underline{41 \mu}$

使用祀量

$$
D \text { : 粒径 }
$$

$D_{50}, D_{99}$ ：重量 50\% 粒径, 通過分重量 $99 \%$ 粒径 $D_{25} *, D_{50} *$, etc. : 補正部分回収率 $25 \%$ 粒径, 同 $50 \%$ 粒径, etc.

$[\mu]$$$
\text { 同 } 50 \% \text { 粒径, etc. }
$$

$f: \log \sigma_{Z_{R}} *$

[н]

$I^{*}$ : 分崔の不完全度

$Q$ ：送入量または排出量

$w_{t}$ ：通過分

[-]

$[-]$

$\boldsymbol{Z}:$ 部分回収率

[ton $/ \mathrm{hr}$ ]

$Z^{*}$ : 補正部分回収草

$[-]$

$[-]$

$[-]$

a：徽粒への分割量

[-]

B : 粗粒への分割量

$[-]$

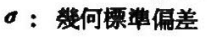

$[-]$

添字

$$
\begin{aligned}
& F: \text { 分般原料 (入物) } \\
& P: \text { 微粒 (精粉) } \\
& R: \text { 粗粒 (もどし物) }
\end{aligned}
$$

\title{
化学プラントショーと化学プラント技術会議を終えで
}

本会は日本能学協会との共催により 10 月 10 日から 6 日間, 第 1 回化学ブラントショーを睛 海の国察貿易センター2 号館において開き，併行して3号館で化学ブラント技術会議を行ない， いずれる成功裏に終了した。以下開催までのいきさつやショーおよび会議の状況を報告し，併 せて明年度以降の計画について私見を述べたい。

\section{開 催まて}

本会では創立 25 周年を記念して 1961 年国際会 議を挙行するとともに，都立産業会館において “化学工業と化学機械展”を開催した。この展示 会は千代田化工建設 (株)の尽力により好評を得， その後す同じような展示会を少なくとす数年こと К1回催してはどうかとの意見が協会内ではしば しば議論されていたが，資金面その他の関保から 実現は容易でなかった。本会はいらまであなく本

\footnotetext{
＂昭和 41 年 11 月 1 日 受理

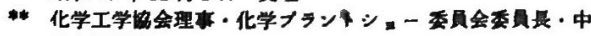
央大学数投
}

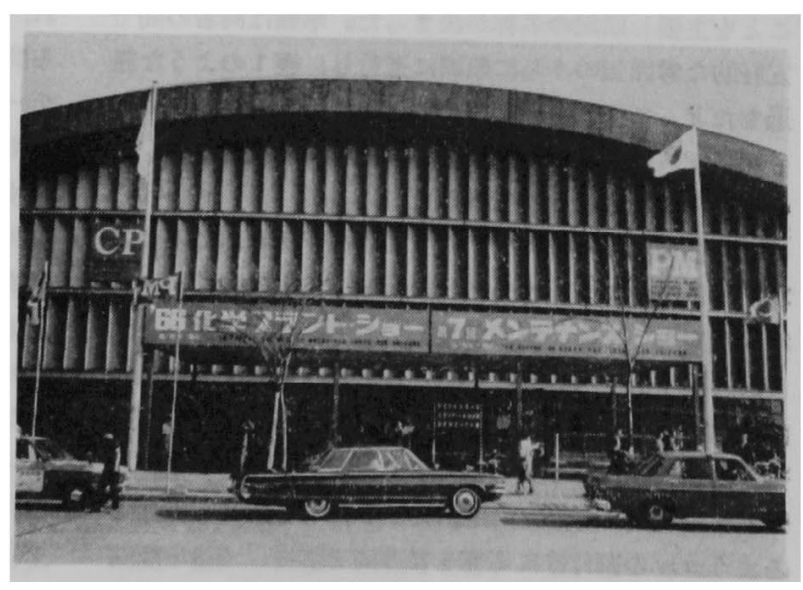

(45) 


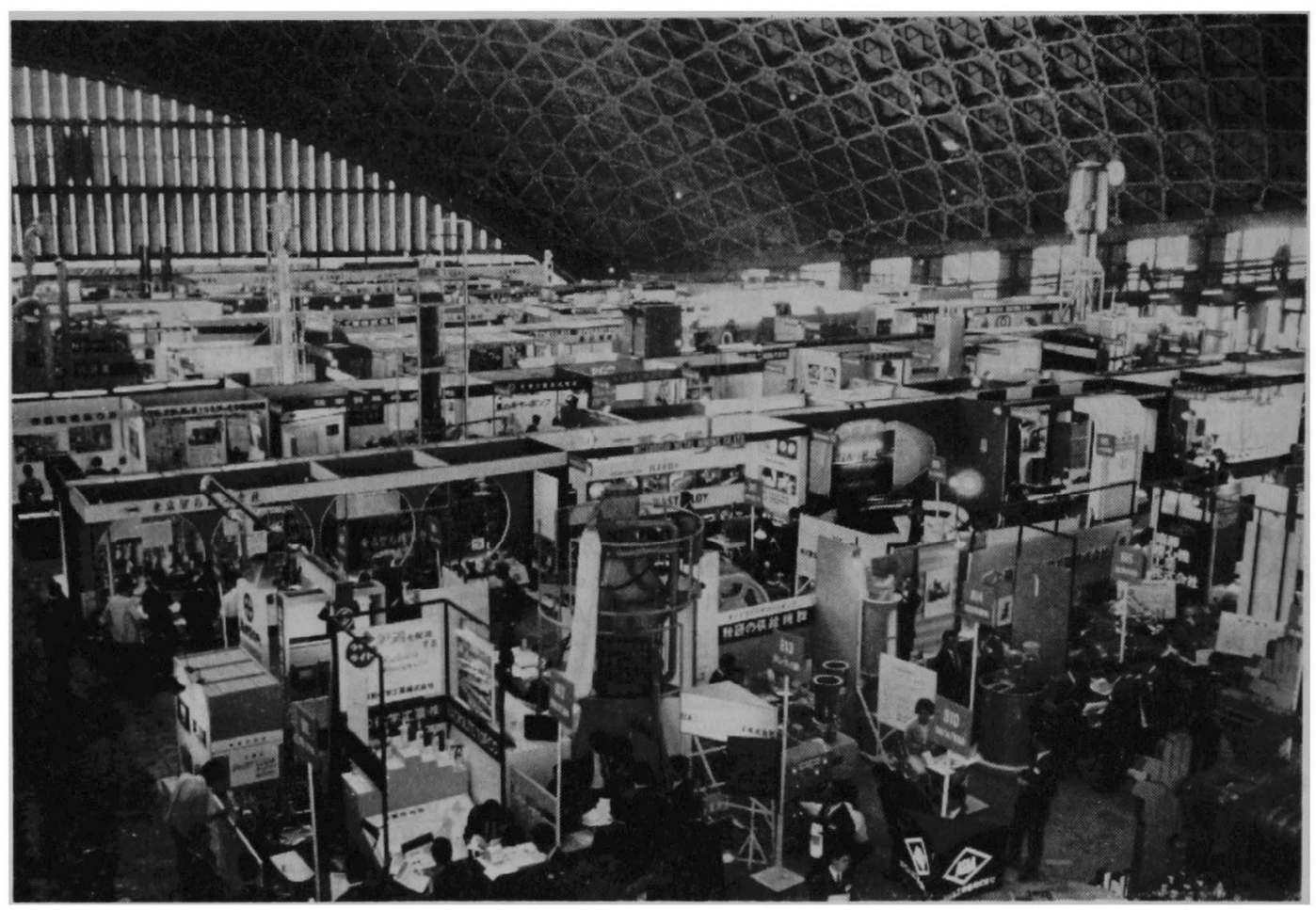

質的には学会であるが，文部省のほか通産省の共管を受 ける社団法人であり，法人会員へのサービスという意味 でもこのような展示会への要望は絶えずあったことは事 実である。本年の始め頃, 日本能率協会から化学ブラン トおよび関連機器に関する専門展示会共催の申し入れが あったとき，比較的スムーズに実現の運びに至ったこと は上記の事情によるものであろう。

日本能率協会は本会の法人会貣でああり, その事業の 一環として過去 6 回のPMショーその他の産業ショービ ジネスアメリカの手法をとり入れ経耠豊かな団体であ る。能孪協会の首脳部の間では頭初化学工業会社をす含 む厷範なショーを考えておられたようであるが，本会で は焦点のぼけるのを防ぐ意味で化学ブラントに限定する ことを主張し頭記の名称が決まった。涿備は両者の間で 友好的な雾囲気の5ちに順調に進行し，表1のよ5な経 過をたどって開催に至っだ。

プリンスホテルでの発表会の席上，筆者はこのショー の狙いとして次の 5 点を举げた。

1. 技術的：化学フラントおよび関連機器に関する 専門展示会であり, 出品会社の企莱 PR よりは技術内容 に重点をおいたショーが望ましいこと。

2.集中的：国際見本市などと異なり一会場に集中 的に展示され，钼客にとっては印象が分散することなく 効果的なイメージが得られること。

3. 系統的：類似の出品はなるぺく並べて展示でき るよらコマの割付けに考虑を払らこと。
4. 継続的：進歩が速やかな業界であるだけに毎年 同じ場所で開催することにより up-to-dateな知識が得 られること。

5. 教育的：化学ブラントおよび関連機器の最近の 傾向や印刷物だけでは得られない実物教育の機会を, 化 工関係の学生，若い技術者に与えること。

以上の隹国際的という点も強調したかったが，さし あたり今回の海外メーカの出品は PR 期間の関係から 3 社淿過きず，次回以降に期待したい。

一方, 化学ブラント技術会議は PMショーと同時に行 なわれる設備管理者全国大会にならい，ショーと併行し て5 日間にわたり開くことが計画された。この会議は人 一カ, ニーザおよび学界の間の討論の場として企画さ れ, テーマとして化学ブラントおよび関連機器のうちか ら問題点の多いと考えられるすのを取り上げた。今回の テーマおよび司会者名, 各テーマごとの参加者数を表 2 に揭げた。原則としてメーカ側を代表する講演者の主題 とする機器はその社から出品されるものとしたので, 多 少テーマの選定に制限があり, 特に単位操作機器として は機械的操作に偏重したきらいはあるが，テーマは毎年 变えることを前提とした。出品があるからといって宣层 にわたる表現はなるぺく避け，客観的な立場で話してい ただくよら各講師にあらかじめ拓願いしておいた。しか し, 結果的にはよい宣伝になったことは事実のようであ る。なお、ショーおよび会議の企画に当たった化学ブラ ントショー委員会（化学工学協会の常置委員会の一つと 


\begin{tabular}{|c|c|c|c|}
\hline & & 表 1 & 程 \\
\hline 月日 & 会 & 名 & お。な决定事项 \\
\hline $\begin{array}{l}1 / 22 \\
2 / 9\end{array}$ & 理事 & 会 & 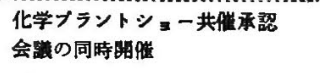 \\
\hline 2/11 & 第1回化学 & シ & 展示方式の大筒 \\
\hline $2 / 16$ & 第2回化学 & ブラントショー & 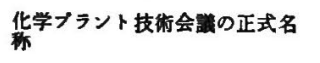 \\
\hline 3/14 & 第3回化学 & ブラントショー & 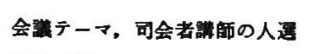 \\
\hline $3 / 23$ & 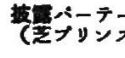 & 的テル) & 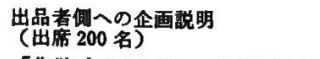 \\
\hline $3 / 30$ & & & 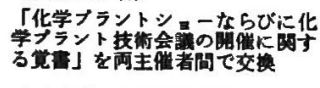 \\
\hline $4 / 1$ & 筆年回化学二 & ブラントンョー & ガイドブックの梮集方制 \\
\hline $4 / 26$ & 篡5回化学 & ブラントシニー & 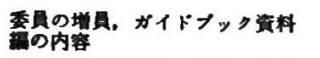 \\
\hline $5 / 13$ & 荟衙会䁌司 & 会者打ち合わせ & 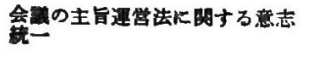 \\
\hline $5 / 31$ & 策6回化与 & ブラントッュー & 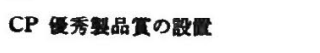 \\
\hline $6 / 9 \sim 6 / 29$ & 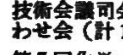 & 会者圆) & テーフ跱打ら合わせ \\
\hline $6 / 28$ & 篓7買会化学 & ブラントシュー & 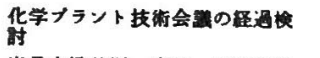 \\
\hline $7 / 15$ & 篓8置会化学 & ブラントッッー & 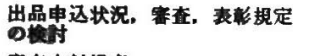 \\
\hline $7 / 26$ & CP 偍秀舞。 & 品寒直委員会 & 塞㚗表新規定 \\
\hline $8 / 31$ & 零員罢 & フシントシー & 企画英施面での最終的模午 \\
\hline $9 / 1$ & 悬者会見ン & スホテル) & 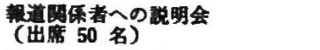 \\
\hline $\begin{array}{r}9 / 6 \\
10 / 7\end{array}$ & 出品者競明 & 会(日䟯ホール) & 出品者への競明会 \\
\hline $\begin{array}{l}10 / 7 \\
10 / 10\end{array}$ & 咸 & 式 & 出品物の嘭入開始 \\
\hline
\end{tabular}

\begin{tabular}{|c|c|c|c|c|}
\hline \multirow[b]{2}{*}{ 開伟日 } & \multicolumn{3}{|c|}{ 化学ブラント技術会議参加者数 } & \multirow[b]{2}{*}{ 加者数 } \\
\hline & $\overline{7}-7$ & 司会者名 & 申迈者数 & \\
\hline 11 & $\begin{array}{l}\text { プロセスガス } \\
\text { ロマトグラフ }\end{array}$ & 大津 & 100 & 97 \\
\hline 11 & 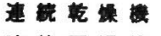 & 粗夈 良三 & 225 & 219 \\
\hline 12 & \multirow{2}{*}{ 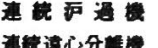 } & 吉铻 普敬 & 213 & 207 \\
\hline 12 & & 高岛 羊一 & 178 & 371 \\
\hline 13 & 粠体供給機 & 青木 臤一 & 244 & 232 \\
\hline 13 & 造 & 東㚼平一郎 & 203 & 184 \\
\hline 14 & スラリーボンフ & 乙竹 & 165 & 163 \\
\hline 14 & \multirow{2}{*}{ 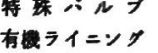 } & 地俱 & 120 & 118 \\
\hline 15 & & 加蕉安二䬦 & 132 & 123 \\
\hline \multirow[t]{2}{*}{15} & 虐水奶理装贯 & 畏伬 & 154 & 144 \\
\hline & & it & 1.784 & 1,658 \\
\hline
\end{tabular}

して設けられた）メンパーを表 3に示した。委員の任期 は 2 年である。

\section{化学プラントショー}

初日である 10 月 10 日が祭日に指定された関保から， 初日には両協会役員と出品者が出席していわば内輪の開 場式を午前 10 時から行ない，11 日に官宁関保泟か後援 団体，両協会の法人会員を招待して開会式を举行すると い5変則的な形をとらさるを得なかった。2 号館の向か って左半分がブラントショ一, 右半分が第 7 回 $\mathrm{PM} シ ョ$ 一となっていて， 入場者数はすへてがブラントショーの 観客とはいえないが，表 4 に示すよ 3 K予想以上飞多く， 事務局の PR もさることながら関係者の関心が深かった

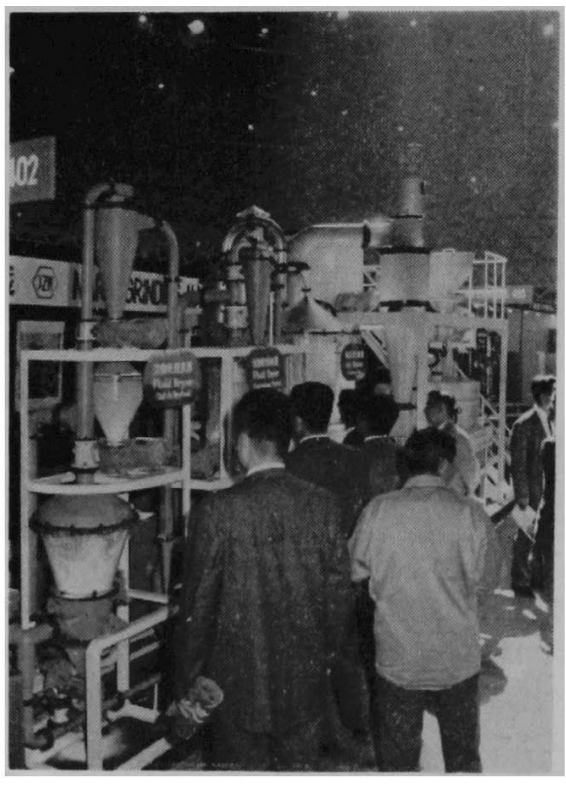

\begin{tabular}{|c|c|c|}
\hline \multirow{3}{*}{ 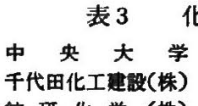 } & \multicolumn{2}{|c|}{ 化学ブラントショー委員会委員名籍 } \\
\hline & 理工学部数报 & 東㚼平一郎 \\
\hline & ث与 & 八藏 \\
\hline 綜 研 化 学 (株) & 取䌅役社長 & 中島 \\
\hline 中部 工莱大学 & 数授 & 高原 知嶬 \\
\hline 日本捙発 油(株) & 研究所研究第 1 部長 & 三䈏 清治 \\
\hline $\begin{array}{l}\text { 東洋エンヂニアリン } \\
\text { 㧣) }\end{array}$ & 建設本部プロセス部主查 & 上床 珍意 \\
\hline 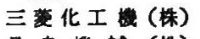 & 川崎䨤作所研究部長 & 黑呮 蓡二 \\
\hline 月島 機 械 (株) & 第 1 技㭪部部長代理 & 中村 良平 \\
\hline 東洋高氏工莱(株) & 技術部主査 & 伐道 \\
\hline 東京工莱試雅 所 & 第 3 部第 4 既長 & 田原 浩一 \\
\hline 味 の 素 (株) & 川崎工场工務部霜部長 & 䳩尾 \\
\hline 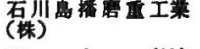 & 化工事莱部管理部企画課長 & 金子 栄一 \\
\hline （妹） & 企画部次長 & 有光 \\
\hline 日 本油胉（珠） & 程管管理部 & 前田 \\
\hline 日本石油䨋震(株) & 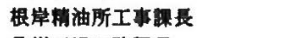 & 体野 弥彦 \\
\hline 三 共 （株） & 品川工域工础踝長 & 高木 万兴 \\
\hline 日本石油化学(株) & 工确踝長 & 浑本大三郎 \\
\hline 日本染色機城（䏭） & 䓪務取籍彼 & 井上 光二 \\
\hline （社）日本能事協会 & 化学ブラントン』ー事破局 & 中島 清一 \\
\hline （社）日本能事劦会 & 化学ブラントショー事䂫局 & 高蕾岸太郎 \\
\hline
\end{tabular}

表 4 日別入場者数 月 日 入者场数

$\begin{array}{rr}10 \text { 月 } 10 \text { 日 } & 14,680 \\ 11 \text { 日 } & 11,773 \\ 12 \text { 日 } & 13,013 \\ 13 \text { 日 } & 13,879 \\ 14 \text { 日 } & 16,434 \\ 15 \text { 日 } & 17,432 \\ \text { 合 } & 87.211\end{array}$

ことを表わしていよ5。10月11 日付日刊工業新聞は 1 ページの写真と記事とを化学ブラントショーにさき， “兄貴分の PM ショーを食った形である”と報した。

化学ブラントショーのコマ ( 9 尺× 9 尺) 数は 241.5, 出品会社数は 109 社で, 実際の出品徑誘に入ってからの 期間が短かった割に消化できたコマ数は多かった。この 


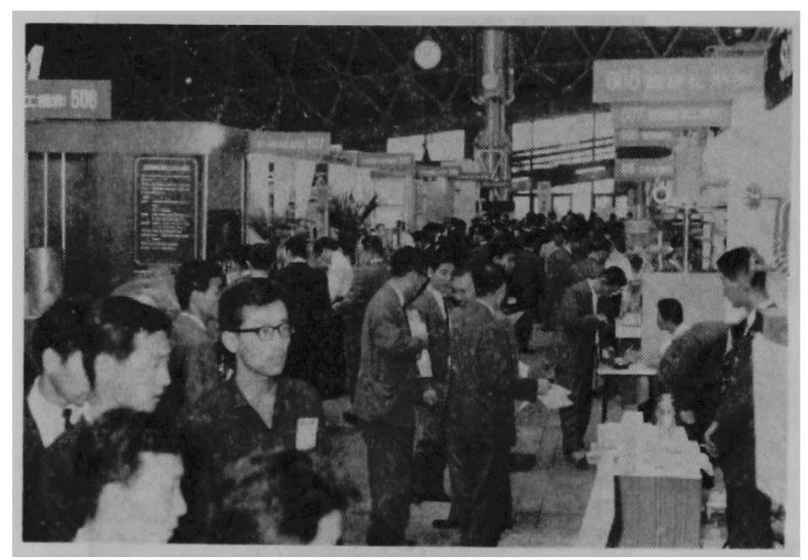

ならする多人数になった。そのため音雷効果その 他の点で参加者にこ迷惑をかけたようである。会 場設営については明年度以降十分検討したい。

なお，質昨応答，討論の要点をる加えた議事錄 が本年中には参加者のお手元に届くはずである。 この議事録は化学ブラントショーのガイドブック ととすに資料として活用いただけるすのと思う。

プラントショー入場者のアン゙ケート調查結果に よると $90 \%$ が関東地区からであったのに対し， 技術会議の参加者の地域別集計によれば関東地区 は50\% К過きない。すなわち地方からのま加が 多く，全国的な催しとして蒛迎すへき傾向であっ た。なお，参加者 1 人当たりの平均参加セッシ

点，事務局の努力K負うところが多いが，同時に本会法

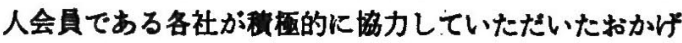
々潹く感揤する次第である。出品内容るかなり充実して いたようである。

ショーの結果を上記 5 項目の狙いから振り返ってみる と,

1. 技術的： $80 \%$ 程度達成されていたように思5。 単一機器メーカはとにかく、エンジニフリング会社の出 品がむずかしいのではないかとの意見が委員会です出て おり、多少の危惧があったが，それそれれ特色を生かした 立派な展示であった。ただ，動く展示物に比較的観客の 関心が集まっていたように見受けられた点，明年度以降 の出品者にこ考虑願いたい。

2. 集中的：会場が㹟くこの点では申し分なかった。

3. 系統的：出品社数が比較的少なく，また一社で数 点の種類の異なった機器を出品された関保で，思 5 上5 な系統的展示はできなかった。しかし，できる範囲で類 似の機種は近くに集めたつもりである。

4. 継綂的：第 1 回が予想以上に盛会であったため, 毎年このショーを継繶する自信を得た。

5. 教育的：長岡工専の 30 名の見学団をはじめ，東 京および近郊の学生多数の参会を得た。この意味から教 有的であるとい5目的は十分達成されたようである。

\section{化学ブラント技術会部}

筆者が参加したセッションは自分の司会する第 6 セッ

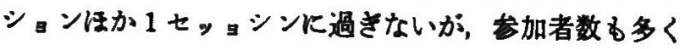
しかもきわめて熱心で質期討論も活発であり，まず成功 であったと思5。化学ブラントショ一の性格からいって む,この会翊はやはり今後とる現場に即した間題を取り 上げるべきであろろ。

企画の段階では人数を效り十分な討論が行なわれるこ とを期したが，申し迈友数が予想外に多く（表 2)，せ っかくの希望をお断わりするのるどうかと思ったので心

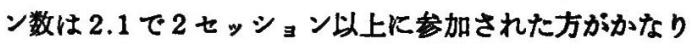
あったことを示している。

\section{明年度の找西}

近日中に委員会が開かれ今回の反省を兼ねて明年度の 計画を討議することになっている。したがって以下は筆 者の私見を含むるのである。

1. 明年度は化学ブラントショーに2 号館全館を当 て, PMショーは1号館で行なう。コマ数は本年のおよ そ2 倍になるわけである。会期は 9 月 25 日から 6 日間 ですすで会場は予的済みである。会期をすっと長くし てはとの意見が特に出品者側から出ているようだが、少 なくとる明年は延長できない。

2. 海外の尃門誌儿案内を載せるなど海外 PR は目下 強力に進めているので，明年度の海外メ一カの出品およ び海外からの観客は大幅によえる見込みである。

3. 本年度の出品锄誘社数はおよそ 1,000 で出品社数 はその 1 割強に過きない。明年度は大手のコマ数を娍ら してあ出品社数を增し、できれば 200 社にはしたい。社 数を增すことは業界の技術開発に対する呼び水とすなる であろ5。

4. ブラントシ ので，共用の応接室をいくつか設けたい。

5. 入場者, 説明者とも名札社名, 職名, 氏名を明 記することを励行したい。

6. 化学ブラント技術会議のテーマ数を堌し，できれ は本年よりは詳細な前刷を作製したい。また，講演者数 をなるへく減じ十分な討論時間がとれるようとしたい。

主催者および日刊工莱新開社で武みている各種のアン ケート，希望調查は目下集計中であって，その結果を参 照しよりよいショーおよび会境にしていきたい。こ意

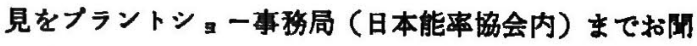
かせいただければ幸いである。最後に業界位のこ協力 を感謝して結びとする。 